\title{
Lesion-Targeted Anti-Cancer Gene Delivery with Clinical Survival Benefits: A Molecular "Rosetta Stone" for Veterinary Hematology-Oncology and Precision Gene Therapy
}

\author{
Erlinda M Gordon ${ }^{1,2,3,4 *}$, Frederick L Hall ${ }^{1,2,3}$ and Sant P Chawla ${ }^{1,3}$ \\ ${ }^{1}$ Cancer Center of Southern California, USA \\ ${ }^{2}$ Delta Next-Gene, LLC, USA \\ ${ }^{3}$ Counterpoint Biomedical LLC, USA \\ ${ }^{4}$ Aveni Foundation, USA \\ *Corresponding author: Erlinda M Gordon, Director, Biological and Immunological Therapies, Sarcoma Oncology Research Center, \\ LLC, Cancer Center of Southern California, 2811 Wilshire Blvd., Suite 414, Santa Monica CA 90403, USA
}

\begin{abstract}
ARTICLE INFO
Received: April 27, 2021

Published: 幽 May 10, 2021

Citation: Erlinda M Gordon, Frederick L Hall, Sant P Chawla. Lesion-Targeted Anti-Cancer Gene Delivery with Clinical Survival Benefits: A Molecular "Rosetta Stone" for Veterinary HematologyOncology and Precision Gene Therapy. Biomed J Sci \& Tech Res 35(4)-2021. BJSTR. MS.ID.005736.
\end{abstract}

Abbreviations: Targeted Gene Delivery; Cell Cycle Control; CCNG1; DeltaRex-G; DeltaVax

\section{ABSTRACT}

This review represents a series of medical hematology-oncology papers by Gordon, Chawla and Hall, composed with the following intents and purposes: (i) documenting significant milestones in Tumor Targeting and Cancer Gene Therapy for the postmodern biomedical and veterinary research communities, (ii) honoring forthright principles of scientific responsibility, regulatory oversight, and informed consent, which serve to protect both human and companion animal health, and (iii) translating FDA-qualified, updated methods \& compositions (CMC and cGMP insights) to veterinary medicine, in light of recent critical analyses, hence gains, in long-term cancer-free survival data achieved in humans. The focus is on tumor-targeted, injectable gene therapy vectors and molecular approaches developed by Gordon and Hall at USC / Children's Hospital Los Angeles-validating "Pathotropic" (disease-seeking) tumor targeting Avant la Lettre. The discussion provides clinical insights into the cellular and molecular mechanisms of both tumor-targeting and tumor-eradication, which led to the formal return of Rexin-G as DeltaRex-G from industrial desuetude to cGMP bioproduction in 2018-2019, with FDA Expanded Access, under a decidedly academic non-profit banner, in accord with historic U.S. "Right-to-Try" legislation. In the spirit of academic fellowship and the interests of a rightfully concerned society, this article provides a molecular (cellular and genetic) "Rosetta Stone" for the responsible translation and biotechnology transfer of these clinically validated U.S. FDA-evolved Pathotropic (i.e., disease-seeking) tumor targeting Methods and Compositions safely to Veterinary Medicine as preclinical safety and efficacy studies in mice, rats, rabbits, minipigs and monkeys were required by the USFDA prior to authorization to use DeltaRex-G in first-in-human clinical trials.

\section{Introduction}

"For love of companion animals" and a deep respect for the distinguished professors and colleagues, who guided a veterinary school graduate student, now a Ph.D. in Physiology and Biophysics, and a physician scientist through the primordial muck of the evolutionary tidepool; through the shapeshifting RNA Worlds of biochemical cause and effect [1]; through the illustrious Kingdoms of the Virus (Virae), the Amoeba (Protozoa), and the lowly Planarian* [2-5], to this prescient pinnacle of mammalian cell biology, cancer biology, regulatory biology, and stem cell epigenetics: a pinnacle upon which the hard-won, hard-core digital logic (hence molecular cybernetics) of site-specific, "Proline-directed Protein Phosphorylation" [6-8] accompanied by phosphorylation-specific- 
proyl (cis-trans) isomerization $[9,10]$ can be viewed as fundamental to understanding medical disorders ranging from dementias of the aging human brain to cell cycle regulation, including the clinical management of metastatic cancers.

In this invited translational research paper, we highlight biomedical, bioethical, and RAC/FDA established principles which served to guide our research into orthopedic limb-salvage, tissue regeneration, wound healing, stem-cell-capture, and metastatic cancer control-from the prestigious think-tanks, operating theaters, ballrooms, courtrooms, and conference tables of modernday princes, royals, and occasional knights**; through the meanstreets of contrarian academics; with it, departmental tycoons and manifold influences of a global pharmaceutical industry; through seasons of testing, trials, and travels in diverse places to this rarefied Vista of Medical History wherein (i) the primal biochemistries, (ii) the molecular genetics, and (iii) the physiological targeting technologies of our shared medical mission have been scientifically validated, affirmed, and restored to rightful intellectual sponsors upon critical analysis of long-term cancer-free survival outcomes. In the spirit of academic fellowship and the interests of a concerned society, this paper aims to provide a molecular / cellular / genetic "Rosetta Stone" for the responsible translation and bio-technology transfer of a broad-spectrum Anti-Cancer Gene Therapy platform with Pathotropic (Tumor-Targeted) Gene Delivery methods and compositions safely to Veterinary Medicine.

*Malignant Reticuloma (a primordial "leukemia") of the Planarian (archived at the U.S. Smithsonian Institute) is considered among the simplest animal models demonstrating chemical cocarcinogenesis [2-5]: that is, initiation and promotion of cancer.

** Prof. Philip Cohen (now Sir Philip Cohen), principle investigator of the renowned MRC Protein Phosphorylation Unit, University of Dundee, Scotland, graciously invited veterinarianscientist Dr. Philip Vulliet and postdoc Frederick Hall, Ph.D., through a NATO-sponsored collaboration, to test / substantiate Dr. Hall's original deduction / hypothesis (of site-specific "proline-directed" protein phosphorylation) with hard-core radio-sequencing of the NGF(nerve growth factor)-sensitive Synapsin I site (a target substrate) by sequential Edman degradation [7].

Proline-directed protein phosphorylation would ultimately expand in scope (and prominence of proline-directed protein kinase regulatory partners) to delineate the biological transduction of vital extracellular signals through receptor-mediated relay mechanisms, identifying linear cascades of digital (reversible, post-translational) phosphotransferase activities (on/off cybernetics) governing the activation and expression of "Executive proto-Oncogenes" in animal stem cells, leading to discovery / characterization of the commanding CCNG1 (Cyclin G1) proto-oncogene and the clinical development of DeltaRex-G (Formerly Mx-dnG1, dnG1, Rexin-G; Figure 1). Table 1 [6-51] highlights epochs of discovery in biomedical research, which flourished at USC / Children's Hospital, Los Angeles, California and further developed through preclinical research (in mice, rats, rabbits, pigs, and monkeys) into far-reaching clinical applications.

Table 1: Discovery Research, Target Validation, and Translation into Clinical Applications.

\begin{tabular}{|c|c|c|}
\hline Scientific Discoveries, Target Validation & Translational Research, Clinical Utility & Refs \\
\hline $\begin{array}{c}\text { The Identification / deduction / validation of "Pro- } \\
\text { line-Directed Protein Phosphorylation" a digital cyber- } \\
\text { netics of cell cycle regulation }\end{array}$ & $\begin{array}{l}\text { Identification and characterization of a novel 'growth-factor-sensitive' pro- } \\
\text { tein kinase that specifically targets -X-Ser/Thr-Pro-X- sites }\end{array}$ & $\begin{array}{l}{[6,7,8]} \\
{[11,12]}\end{array}$ \\
\hline $\begin{array}{c}\text { Proline-Directed Protein Kinase Cascades: Characterizing } \\
\text { S-Phase Promoting Factor, Oncogene Activation, Tumor } \\
\text { Suppression }\end{array}$ & $\begin{array}{l}\text { EGF and Factor XII signaling via Mapk/Erks; Characterization of the Rb-inac- } \\
\text { tivating CDKs; "Cyclins" as the Targeting Subunits of CDKs }\end{array}$ & $\begin{array}{l}{[13,14]} \\
{[15,16]}\end{array}$ \\
\hline $\begin{array}{l}\text { Targeted Growth Factors, Wound Healing, and (P4) } \\
\text { Mesenchymal Stem-Cell-Capture }\end{array}$ & $\begin{array}{l}\text { Recombinant lesion-targeted fusion proteins } \\
\text { P4 MSC-capture, expansion for gene therapies }\end{array}$ & $\begin{array}{l}{[17,18]} \\
{[19,20]}\end{array}$ \\
\hline $\begin{array}{l}\text { Molecular Cloning, Characterization } C C N G 1 \text { Knockout of } \\
\qquad C C N G 1 \text { (Cyclin G1) Oncogene }\end{array}$ & $\begin{array}{l}\text { Cloning/characterization of human Cyclin G1 } \\
\text { and its essential function in cancer cell growth }\end{array}$ & $\begin{array}{l}{[21,22]} \\
{[23-25]}\end{array}$ \\
\hline $\begin{array}{l}\text { Molecular Cloning of human CAK1 (Cdk7), MAT1, a } \\
\text { CDK7-assembly factor, and Cyclin G1-associated p18 } \\
\text { (FX3); aka p18 Hamlet }\end{array}$ & $\begin{array}{l}\text { Inhibition of keratocyte cell proliferation by retroviral transfer of antisense } \\
\text { Cyclin G1 or MAT1 constructs - to prevent corneal haze }\end{array}$ & [26-29] \\
\hline $\begin{array}{l}\text { Pathotropic (disease-seeking) Gene Vectors } \\
\text { "Killer Gene" }(d n G 1) \text { embodied in DeltaRex-G Targeted de- } \\
\text { livery of a dnG1 "silver bullet" Tumor Targeted/Personal } \\
\text { Cancer Vaccines DeltaVax }(G M-C S F / t k) \text { Vector }\end{array}$ & $\begin{array}{c}\text { Targeted, Injectable gene delivery platforms Preclinical demonstrations of } \\
\text { safety, efficacy; broad-spectrum activity, tumor killing, survival Tumor-tar- } \\
\text { geted gene-therapy/immuno-therapy, benefits in chemo-resistant metastatic } \\
\text { cancers }\end{array}$ & $\begin{array}{l}{[30-32]} \\
{[33-36]} \\
{[37-40]} \\
{[41-43]}\end{array}$ \\
\hline $\begin{array}{l}\text { Counterpoint Onco-Aptamers for tumor-targeting of } \\
\text { Taxol, Mabs, and future siRNAs }\end{array}$ & $\begin{array}{c}\text { Customized Targeting/Adaptor-peptides: Add pro-active targeting to FDA-ap- } \\
\text { proved drugs }\end{array}$ & {$[44,45]$} \\
\hline $\begin{array}{l}\text { Long Term Survival Benefits (and the U.S. Right-to-Try } \\
\text { Legislation) prompt the timely restoration of DeltaRex-G }\end{array}$ & $\begin{array}{l}\text { Analysis of tumor histology, cancer stem cell eradication, immunology, long } \\
\text { term ( } \geq 10-12 \text { year) cancer-free survival duly validate DeltaRex-G }\end{array}$ & [46-51] \\
\hline
\end{tabular}




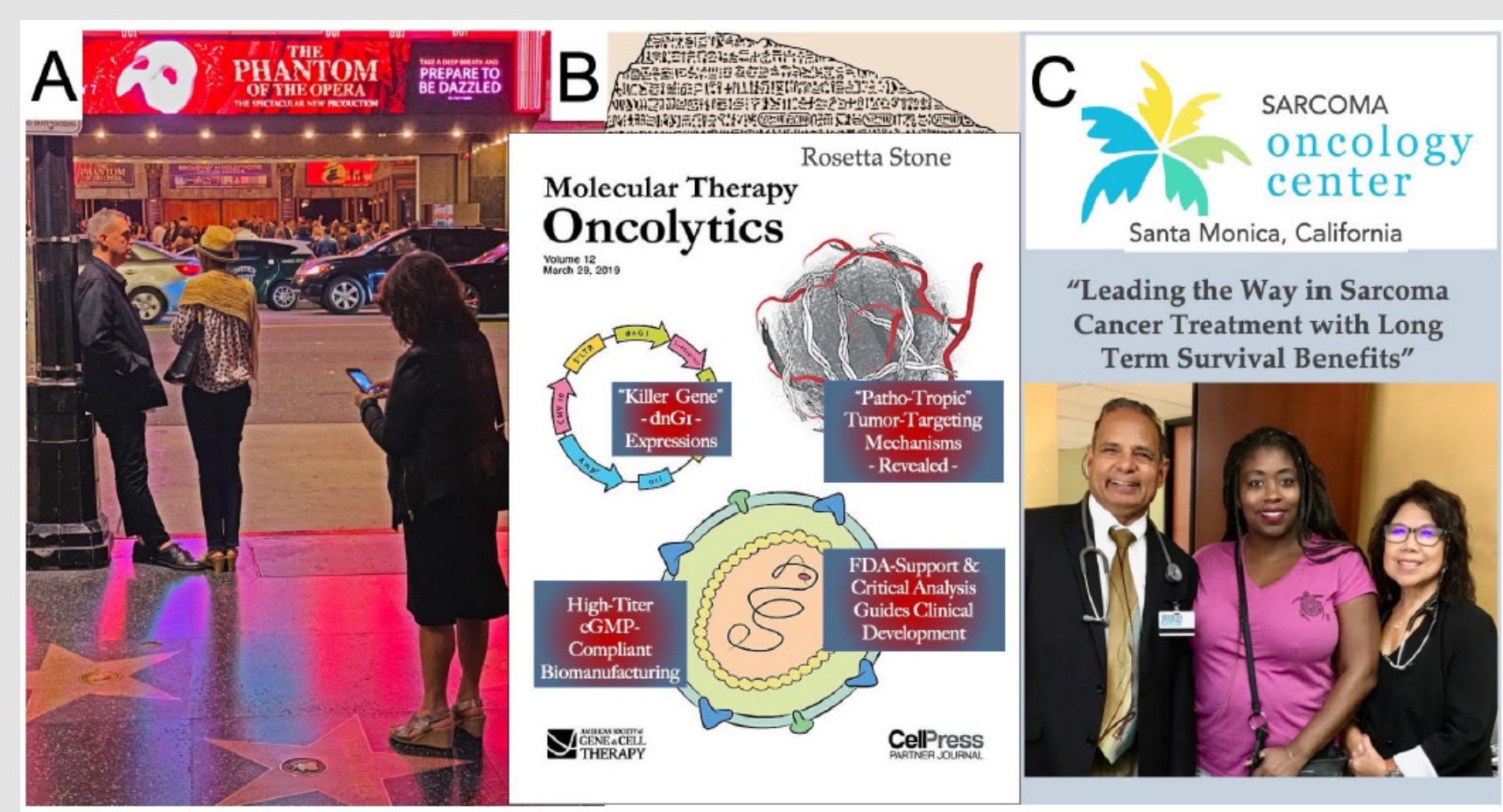

Figure 1: Dr. Erlinda Maria Gordon et al., on a starlit Hollywood Boulevard, Los Angeles, California. (A), celebrating epochs of Gene Discovery, Translational Research, and Clinical Validation, (B), enabling DeltaRex-G to be regenerated, restored, and ultimately returned with cGMP in hand to cancer patients everywhere, and (C) annus mirabilias, 2019 showing Left to Right: Dr. Sant Chawla, Director of the Sarcoma Oncology Center, Santa Monica CA, a 12-year cancer survivor with DeltaRex-G therapy, and Dr. Gordon.

\section{Targeting the Executive Proto-Oncogenes of Animal Stem Cell Competence}

\section{Mechanistic Focus on the Pivotal, Commanding Cyclin G1 / Cdk / c-Myc / Mdm2 / p53 Axis}

The mechanisms of proline-directed protein phosphorylation governing cell cycle activation, entry, metabolic growth, progression, DNA replication, and cell division are highly conserved. Indeed, the identification of core checkpoint control mechanisms dependent on coordinated cyclin-dependent kinase (Cdk) activities (i.e., Cyclins) and phosphatase activities (i.e., PP2A-regulators) has been recapitulated in what seems like " $a$ zillion" moleculargenetic screens [52]. Enter the human CCNG1 (Cyclin G1) protoOncogene which was identified by molecular genetics [21,53], and characterized functionally in terms of gene expression / knockout in human osteosarcoma cells [22], which often lack TP53 (p53) tumor suppressor function entirely.
What was once considered controversial, in terms of Cyclin G1 function in neoplastic transformation and oncogenesis vis-àvis p53-mediated tumor suppression [54-57], has been clarified by direct experimentation, informative preclinical studies, and pioneering "tumor-targeted" gene therapy applications complete with clinical validation of (i) histological, (ii) cellular, and (iii) molecular mechanisms-of-action [36-40], providing (iv) long-term, cancer-free survival outcomes [46-51]. Figure 2A reveals with clarity the potential diagnostic and therapeutic insight the hardcore structure/function relationships described operationally as the Cyclin G1-Cdk / cMyc / Mdm2 / p53 Axis the axis mundi of Stem Cell Competence-which links CCNG1 expression and the resulting Cyclin G1-dependent phosphotransferase activities to stem cell activation and oncogenic transformation (see Figure 2B), revealing a potential for broad-spectrum clinical utility in the management of advanced metastatic cancers, based on bioactive tumor targeting, and hardwon molecular-genetic control of this commanding oncogenic driver. 

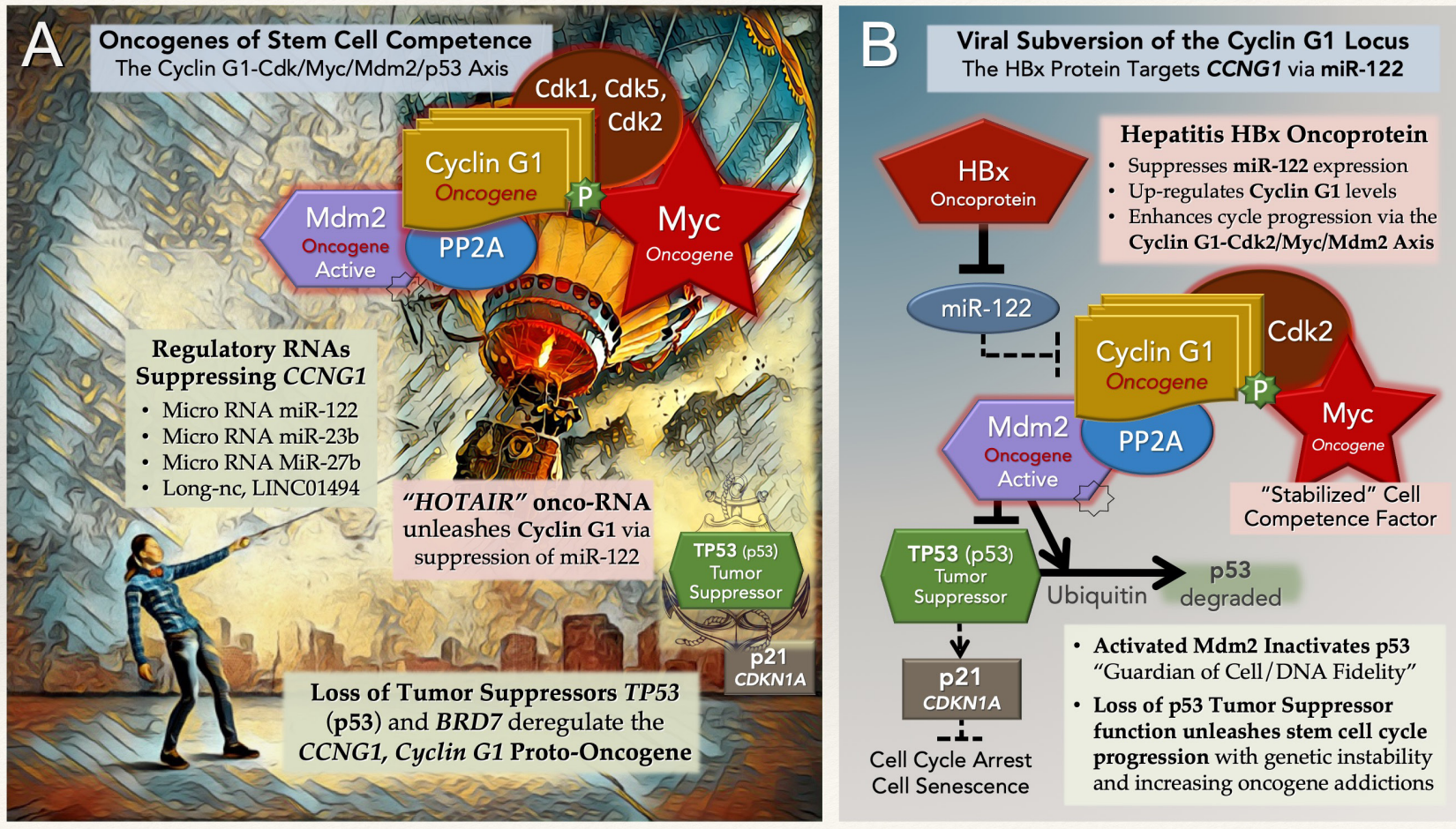

Figure 2: The pivotal and commanding Cyclin G1-Cdk / cMyc / Mdm2 / p53 Axis, shown here figuratively in panel (A), revealing a fundamental relationship between the lofty Cyclin G1 Oncogene (a Survival factor) and the TP53 (p53) Tumor suppressor, socalled Guardian of DNA sequence fidelity and Executioner of aberrant cells. By "targeting" PP2A to dephosphorylate / activate the Mdm2 oncogene product-a negative regulator of p53 activity and p53 stability - CCNG1 (Cyclin G1) expression, which maintains cell survival during the processes and checkpoints of DNA Repair, is subject to molecular-genetic dysregulation resulting in oncogenic transformation, along with degradation of TP53 (p53) Guardian/Executioner function. The viral subversion of the CCNG1 locus is shown in panel (B), where Cyclin G1-dependent CDK-phosphorylation of the cMyc Competence Factor, specifically at Ser-62, activates and stabilizes this otherwise short-lived protein, upregulating gene expression programs, hence feeding forward from stem cell senescence to engage the cyclic biochemistries of cell cycle progression (G0 to G1).

Stem Cell Activation, leading to stem cell growth, DNA synthesis, and mitotic cell division, is orchestrated by the expression and biochemical functions of "Cyclins," a conserved family of executive regulatory proteins that function as intracellular targeting-subunits for their cognate cyclin-dependent, proline-directed protein kinase (CDK) partners. The Cyclin Proteins, named alphabetically in order of their discovery and molecular cloning in animal cells, are defined structurally by a characteristic Cdk-interacting domain, the so-called "cyclin-box." Cyclins are divided operationally into subfamilies as either (i) "Canonical Cyclins" (Cyclins A1 to E2), which bind/ target/activate Cdks of the cell division cycle; (ii) "Transcriptional Cyclins" (e.g. Cyclin H) which are involved in the regulation of RNA polymerase; and (iii) "Atypical or Orphan Cyclins," including CCNG1 (Cyclin G1), which is considered both canonical: Cyclin G1/Cdk heterodimers target/phosphorylate/stabilize the cMyc competence factor, and transcriptional: the p53 tumor suppressor and the Cyclin G1 Survival factor normally cooperate in mediating genomic stability and DNA damage repair in somatic cells, integrating cell survival and cell death decisions during the process of cell differentiation [57-60]. Indeed, the Cyclin G1-associated p18 FX3 zinc-finger (DNA-binding) protein first identified at USC / CHLA in a molecular-genetic screen for human Cyclin G1-interacting proteins [28]-was re-named "Hamlet" in Britannia and Spain [61] upon demonstrations that this transcriptional coactivator provides an important link between extracellular (MAPK) signaling pathways [11], CCNG1 gene expression, and p53-dependent life-ordeath cell-fate decisions: Transcriptionally p18 Hamlet regulates (i) p53-dependent pro-apoptotic responses to DNA damage-inducing agents [62], as well as natural (ii) epigenetic mechanisms regulating gene activation and muscle stem cell functions [63] located at the headwaters of tissue repair, myogenesis, and muscle stem cell differentiation [64] hence, potential for limb regeneration.

The Cyclin G1-Cdk / cMyc/ Mdm2 / p53 Axis is illustrated in Figure 2A: expression of CCNG1 (Cyclin G1) is controlled by a number of suppressive RNA species, including microRNAs miR122, miR-23b, miR-27b, and long non-coding RNA LINC01494 [6570 ], the loss of which results in the upregulation of CCNG1 (Cyclin G1) and the Cyclin G1/PP2A-dependent activation of the Mdm2 oncoprotein, a negative regulator of p53 [56]. The expression of 
the Cyclin G1 onco-protein physically binds and targets a cellular cyclin-dependent kinase partner (Cdk1, Cdk2, or Cdk5) to the cMyc Competence Factor [71,72], whereby the phosphorylation of cMyc at Ser-62 [73-75] "stabilizes" this key oncogenic transcription factor, thereby activating gene expression through " $E$-box" promoter elements of particular genes associated with stem cell proliferation, maintenance of pluripotency, progression to cancer, and metastasis.

Mutational loss of the tumor suppressors BRD7 and/or TP53 [76,77] upregulate CCNG1 oncogene (Cyclin G1) expression, amid increasing genetic instability, as does the molecular suppression of miR-122 by the long non-coding RNA named HOTAIR, a novel type of "RNA-oncogene," whose expression is linked to cancer metastasis [78,79]; as does viral subversion of the CCNG1 gene locus by the hepatitis B virus (HBV) X-protein ( $\mathrm{HBx}$ ), whereby direct suppression of miR-122 expression "unleashes" CCNG1 (Cyclin G1) expression, which drives hepatoblastoma cell proliferation [80].

\section{Molecular Engineering and Precision Delivery of the DeltaRex-G "Silver Bullet:"}

\section{A Dominant-Negative Cyclin G1 (dnG1) Inhibitor for Broad Spectrum Anti-Cancer Gene Therapy}

The executive role of CCNG1 expression in governing the activation and stability of $\mathrm{cMyc}$ and $\mathrm{Mdm} 2$ core onco-proteins governing Stem Cell Competence is revealed in the bifurcation of structure-function relations attributable to the Cyclin G1 protein, as illustrated in Figure 3A. The corresponding structure of the dominant-negative (dnG1) killer gene, a Cyclin G1 Inhibitor, (aka dnG1 Silver Bullet) developed for advanced metastatic cancers is shown in Figure 3B. In designing the cytotoxic "dnG1" construct, Hall and Gordon purposefully eschewed molecular antisense constructs and point mutations in the "cyclin box" domain, which were indeed insightful in terms of elucidating molecular mechanisms and essential functions; however, such constructs are considered nonoptimal in terms of blocking robust signal transduction pathways wherein the catalytic turnover rates $\left(k_{c a t}\right)$ of protein kinase and phosphatase reactions are measured in seconds, and resulting phosphorylation-dependent stabilizations, assemblies, and enzyme activities of key regulatory proteins have wide ranging cellular implications involving cell life-or-death decisions.

The dominant-negative dnG1 expression construct embodied in DeltaRex-G, is delivered intravenously yet selectively to tumors via a physiologically-active Pathotropic (disease-seeking), tumorsurveilling gene expression vector [30-40], which performs clinically as a broad-spectrum anti-cancer agent: blocking Cyclin G1-dependent survival pathways in chemo-resistant cancer cells derived histologically from differing germ layers (e.g. pancreatic cancer, soft tissue sarcomas, osteosarcoma, and breast cancer): enforcing apoptotic death in cancer cells and cancer stem-like cells, blocking tumor-associated neo-angiogenesis, resolving lymphatic metastasis, and restoring and/or enhancing anergic tumor immune responses.

\section{The Survival Value of Bio-Active Tumor Surveillance}

The Clinical Performance of DeltaRex-G a retroviral expression vector bearing an inhibitory construct of Cyclin G1 represents a milestone in Medical Nanotechnology [81], as well as Cancer Gene Therapy and Immunotherapy. Documentation of physiological tumor targeting, apoptotic mechanisms-of-action, dose-dependent bio-pharmacology, primary tumor eradications, metastatic cancer eradications, and dose-dependent survival benefits have all been demonstrated formally, within the guidance and confines of regulatory oversight, leading to USFDA orphan drug and fast track designations for pancreatic cancer, soft tissue sarcoma and osteosarcoma, and PhFDA accelerated approval for all solid malignancies deemed refractory to standard chemotherapies in 2007 [36-40,82,83], and Expanded Access for DeltaRex-G for solid malignancies such as pancreatic cancer, sarcoma, breast and prostate cancer, cholangiocarcinoma, NSCLC and Emergency Use Authorization for Severe COVID-19 [46-51] in 2020.

As defined by the NCI, Retrovector Encoding Mutant AntiCyclin G1, DeltaRex-G, is a replication-incompetent, pathotropic, tumor / matrix (collagenous SIG)-targeted, retroviral vector encoding an $\mathrm{N}$-terminal deletion mutant form of the Cyclin G1 gene with potential antineoplastic activity. Under the control of a hybrid long-terminal repeat/cytomegalovirus (CMV) promoter, retrovector encoding mutant anti-cyclin $\mathrm{G}$ expresses the mutant cyclin G1 construct, resulting in disruption of tumor cell cyclin G1 activity and decreased cellular proliferation and angiogenesis. This agent preferentially targets collagen (SIGs) of the tumor matrix because of the incorporation of the collagen-binding domain of von Willebrand factor (vWF) on the retrovector surface. Exploiting the collagen-targeting mechanism of vWF permits delivery of the retrovector to tumor sites where angiogenesis and collagenous matrix exposure occur (NCI Thesaurus).

DeltaRex-G represents a potential cross-species "dnG1 Silver Bullet" for advanced metastatic cancers: Enforced expression of dnG1, a Cyclin G1 Inhibitor, blocks hyper-competent survival pathways, restores lost tumor suppression (via enforced apoptosis), and disrupts core oncogene addictions characteristic of cancer stem cells (Figure 3A). Designed to function physiologically (indeed, pro-actively) amid the turbulence, flow, shear forces, filtration, immune inactivation, and manifold dilution factors encountered within the systemic circulation, the (anaplasia, pan-Col) SIGtargeted DeltaRex-G expression vector seeks-out and accumulates selectively in cancerous lesions-including inoperable primary tumors, remote metastatic lesions, and even lymphatic drainagedemonstrating objective, quantitative, dose-dependent anti-cancer activities, including tumor necrosis, overt anti-angiogenesis, tumor eradications, and lymphatic clearance; leading to clinical remissions with survival benefits, as summarized in the following "Bullet Points" describing the targeted anti-cancer bioactivity of DeltaRex-G with histopathological precision: 


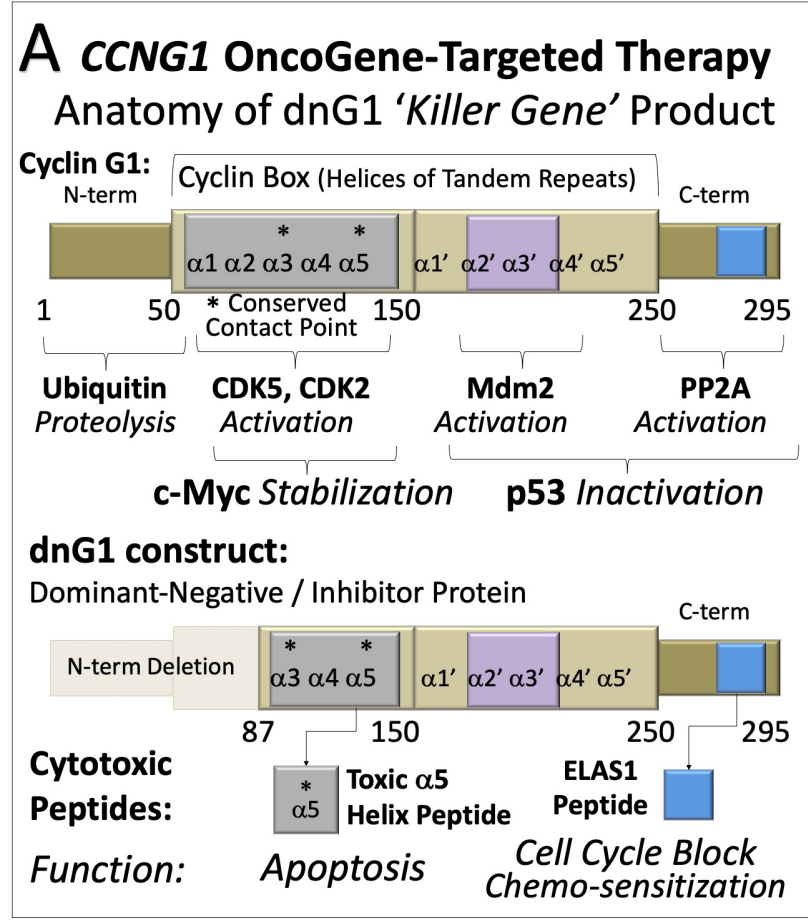

\section{B DeltaRex-G Vector BioProduction} Approved CMC, cGMP, Bioprocessing
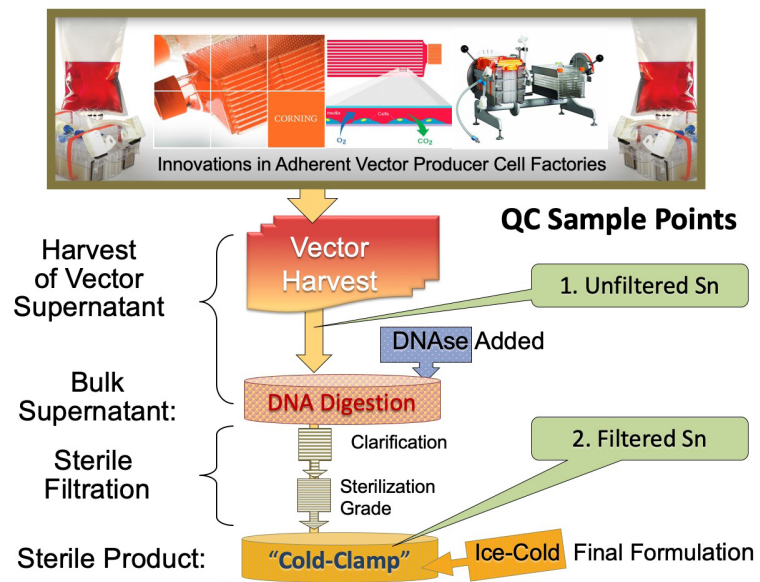

Final Fill

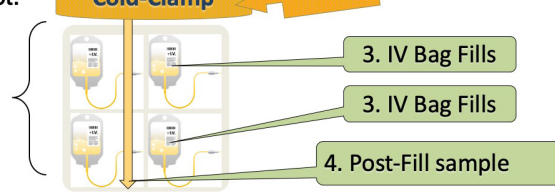

Figure 3: Structure of Cyclin G1 in relation to the dominant-negative dnG1 killer geneRx construct.

(A) The dnG1 protein, a dominant-negative mutant construct of Cyclin G1, is devoid of the N-terminal segments involved in proteolytic processing, as well as the first two helical segments (a1 and a2) of the definitive "cyclin box," characteristically arrayed in canonical cyclins as a tandem set of helical segments, including two highly conserved residues (asterisks) essential for Cyclin-dependent kinase (Cdk) binding. The cytocidal dnG1 protein, which induces apoptosis in proliferative cells, retains the deduced Cdk contact points (Helix a $3^{*}, \mathrm{a}^{*}$ ) and the structural domains attributed to PP2A- $\beta^{\prime}$ and Mdm2 binding. Remarkably, several therapeutic peptides (e.g., ELAS1 and a5 Helix peptides) derived from structures or homologous interfaces contained within the truncated dnG1 protein are reported to induce cell cycle blockade and apoptosis, respectively. (B) CMC, BioProduction, and Bioprocessing of DeltaRex-G (dnG1) gene vector.

1. Delta-Rex-G targets proliferative tumor cells, cancer stem cells, and tumor-associated fibroblasts;

2. Delta-Rex-G targets angiogenesis: tumor-associated stroma, endothelial cells, and immune cells;

3. DeltaRex-g exhibits excellent clinical safety, dose-dependent responses, single-agent-efficacy (monotherapy);

4. DeltaRex-G exhibits broad-spectrum bioactivity in advanced, chemo-resistant metastatic cancers;

5. Notably, DeltaRex-G penetrates and 'clears' the lymphatic system of metastasis, over time; and

6. Delta-Rex-G restores immunity while eliminating chemotherapy-resistant cancer stem-like cells.

Piloted by a unique (tumor-seeking) navigational guidance system, the DeltaRex-G expression vector physically delivers: it enters, downloads itself (reverse transcribes its RNA-to-DNA) and enforces the expression of the cytocidal "dnG1 Silver Bullet" in the proliferative tumor cells of primary and metastatic lesions: in transformed cancer cells, proliferative tumor neo-vasculature, myofibroblast-like stromal cells, and tumor immune cells arresting tumor growth (in size and metabolic activity), arresting tumor neoangiogenesis, and restoring / enhancing both innate and adaptive immune responses [36-40], including the phagocytic clearance of tumor debris $[37,84]$, as documented by a detailed histological and cytological analysis of immune cell trafficking in the tumor microenvironment of DeltaRex-G (Cyclin G1 inhibitor)-treated tumors [48,85-88].

"The realization that the gene delivery function (i.e., cytocidal activity) of pathotropic nanoparticles remains active as it penetrates metastatic disease within sentinel lymph nodes and does not disrupt but appears to work in concert with the immune system, reaffirms the potentiality of future cancer vaccinations in situ, using this targeted gene delivery system bearing a cytokine gene." [37].

The ability of DeltaRex-G to work in concert with the cancer patient's own immune system in managing tumor eradication encouraged the development of a New Generation of Gene Delivery Vectors, which "target metastatic cancers from the inside" [41], enabling the conception and clinical development of The 
Genevieve Protocol: an innovative Dual Targeted Approach to Cancer Gene Therapy / Immunotherapy. The protocol introduced a second treatment (post-dnG1) as adjuvant immunotherapy, deploying DeltaVax (formerly Reximmune-C), a pathotropic tumortargeted cytokine vector, which pro-actively delivers the immunostimulatory GM-CSF gene (expressed, pulsed) to 'residual tumor cells' to enhance localized tumor immune responses and improve treatment outcomes thereby demonstrating prolonged survival times and advancing the medical concept of Personalized Cancer Vaccinations (in situ auto-vaccinations) as a realistic and nowachievable clinical goal [41-43].

Moreover, Hall and Gordon subsequently adapted pathotropic (disease-seeking) targeting technologies to therapeutic proteins to enable the targeted delivery of monoclonal antibodies (mAbs) with a series of synthetic targeting peptides (named Onco-aptamers) $[44,45]$, designed to bind physically (upon mixing) and pro-actively deliver existing off-the-shelf FDA-approved humanized monoclonal IgGs to tumors: including anti-tumor cell mAbs, anti-angiogenesisacting mAbs, and / or the popularized immune checkpoint inhibitors, which continue to elicit serious immune-related adverse events [89], when left un-tethered. Pathtropic Targeting was developed by Hall and Gordon et al. at the turn of the century, a time in the history of molecular-genetic medicine when the collective opinion of the pharmaceutical industry was decidedly negative, having harvested a clutch of U.S. taxpayer-funded research programs, intellectual properties, and fledgling biotechnology companies, with nary a clinical gene therapy treatment nor product in sight. According to an astute industry analysis at the time:

\section{Researchers Get a Dose of Reality as Logistics Stymie Gene} Therapy

by Robert Langreth and Stephen Moore, The Wall Street Journal, 1999

"From the Beginning, the therapy's main difficulty has been a logistical one: how to deliver enough healthy genes to the appropriate site and get them to stay there long enough to cure or alleviate a disease" [90].

It is in this context of strained academic and scientific responsibilities that the inspired research collaboration of Hall and Gordon advanced as a concerted and enduring medical mission: research in biological signal transduction, stem cell biology, hematology, oncology, molecular genetics, and translational research (Table 1)-working together (i) to capture primitive $\mathrm{P} 4$ mesenchymal stem cells for wound healing and tissue regeneration, (ii) to target growth factors and other therapeutic agents in an effort to treat / vascularize / heal injured and diseased organs, (iii) to identify, characterize, and harness rate-limiting oncogenes governing stem cell competence and neoplastic transformation, and finally (iv) to conceive, reduce-to-practice, optimize, and manufacture biologically safe, pathotropic, replication-incompetent gene delivery/therapy vectors for clinical applications in oncology in accordance with the evolving expectations, scientific understandings, FDA-guidance, and "informed consent" befitting a rightfully concerned society.

Fortunately, the passage of recorded time in relation to clinical outcome has an impeccable form of sanctity. It is the clinical safety, anticancer efficacy, and survival value of repeated DeltaRex-G infusions demonstrated in the crucible of clinical oncology (in chemotherapy-resistant metastatic cancers), where investigational new drugs (INDs) and clinical protocols are contested, adverse events and cancer-free remissions are dutifully recorded [4751], and long-term patient follow-up is formally mandated by the U.S. FDA. In view of actual long-term cancer-free survivors now exceeding 10-12 years of cancer-free survival, in certain hard-totreat chemotherapy-resistant metastatic cancers [see 85-88] it is clear that overall survival (OS) represents a New Gold Standard for evaluating treatment outcomes of metastatic cancer therapies, which amounts to somewhat more than an academic milestone [91].

Critical analysis in aggregate and individual case studies over the years [92,93] has revealed molecular mechanisms of action and resulting tumor cell responses in graphic detail, as the histological processes of tumor necrosis and tumor eradication emerged: eliminating troublesome chemotherapy-resistant cancer cells and their stromal accomplices along with troublesome cancer stem cells, which cannot escape the physiological tumor surveilling function of the pathotropic DeltaRex-G nanoparticles.

A recent discovery in myeloid neoplasms focused attention on CCNG1 as a protooncogene: Geneticists at Harvard University and the Mayo Clinic recently reported on a novel oncogenic gene mutation-specifically, an IGH-CCNG1 Gene Rearrangement found in a patient with chemotherapy-induced acute myeloid leukemia (AML), thus sounding alarm bells for medical oncology; and yet identifying DeltaRex-G (Cyclin G1 inhibitor) astutely as a potential new treatment for such deadly AML. According to Dr. Sheng Xiao et al. of Harvard University:

"Clinical trials with a dominant-negative CCNG1 retroviral expression vector (DeltaRex-G) showed impressive results, including several metastatic tumors being cancer-free ten years after DeltaRex-G monotherapy.... It will be interesting to evaluate how frequent the CCNG1 is overexpressed in myeloid tumors, and whether an anti-CCNG1 strategy such as DeltaRex-G is effective in treating myeloid tumors, a group of diseases typically with very poor prognosis" [94].

Consistent with these findings, Gordon et al. have confirmed that the CCNG1 (Cyclin G1) gene is highly expressed in numerous advanced cancers, independent of TP53 (p53), and are currently developing companion diagnostic assays to identify patients who are likely to benefit from DeltaRex-G [95]. This molecular genetic 
discovery of an oncogenic breakpoint translocation within the CCNG1 gene promoter region is both clinically and mechanistically revealing: (i) it introduces and exhibits real-world molecular oncology of gene expression enhancers and (ii) it confirms that the overexpression of the Cyclin G1 is sufficient, by itself (via the Cyclin G1 Axis; see Figure 2A), to actually cause cancer: in this case, an acute and rapidly-fatal myeloid leukemia.

The complex circuitry regulating CCNG1 (Cyclin G1) expression in the presence and absence of inactivating TP53 (p53) mutations can now be examined at the level of the gene promotor: Gene promoters contain several classes of functional sequence elements (cis elements) recognized by regulatory proteins, various transcription factors, and essential components of the transcriptional machinery. Mechanistically, a particular cis-element (TCTCGCGATA motif) is found in the promoter regions of both the $c M y c$ and CCNG1 protooncogenes [96]: the motif appears to be critical for the expression of genes involved in enhancement of protein synthesis during the early phases of the cell division cycle. This cis-element is duplicated in CCNG1, as it is duplicated in a subset of transcription factors,

Table 2: Target Validation and Molecular Mechanisms-of-Action. translation initiating factors, and ribosome proteins involved in cell cycle activation and entry [96].

Another key to understanding the coordinated activation and cell-cycle regulation of cMyc, Cyclin G1, and Mdm2 proto-oncogenes $[50,51]$ is the so-called Specificity protein 1 (Sp1), a transcription factor (family) that exerts its effects on genes containing GC-rich Sp1binding sites within their promoters-the transcription of which mediates processes of cell growth, differentiation, angiogenesis, stem cell programming and tumorigenesis [97]. Of clinical interest, as an adjuvant treatment, are reports that anti-cancer activity induced by oleanolic acid, a natural pentacyclic triterpene [98,99], is manifested at least in part at the level of CCNG1 (Cyclin G1) gene expression: suppressed in lung carcinoma cells by an increase in abundance of miR-122 [100], a natural CCNG1 (Cyclin G1) gene suppressor that is commonly lost with the progression of cancers. See Table 2 [101-108] for additional newsworthy research reports supporting the unifying concepts, themes, and biochemistries presented herein.

\begin{tabular}{|c|c|c|}
\hline Focus on "Target Validation" & Mechanisms and Commentary & \\
\hline $\begin{array}{l}\text { CCNG1 (Cyclin G1) dys-regulation by p53-mutation... } \\
\text { promotes high-grade ovarian cancer tumorigenesis and } \\
\text { progression. }\end{array}$ & $\begin{array}{l}\text { CCNG1 promoted both tumor cell motility by inducing epithelial-mesen- } \\
\text { chymal transition (EMT) and resistance to cisplatin. In vivo knock-down } \\
\text { of CCNG1 expression inhibits cancer metastasis. }\end{array}$ & Xu et al. [101] \\
\hline $\begin{array}{l}\text { Cyclin G1 mediates the poor prognosis of breast cancer } \\
\text { through expanding the population of cancer stem cells. }\end{array}$ & $\begin{array}{l}\text { Elevated Cyclin G1 expression was indicative of lower OS; Cyclin G1 } \\
\text { plays an important role in expansion of cancer stem cells, chemotherapy } \\
\text { resistance, and poor prognosis in breast cancer. }\end{array}$ & Luan [102] \\
\hline $\begin{array}{l}\text { Cyclin G1 drives maladaptive renal repair. Cyclin G1 } \\
\text { regulates kidney epithelial cell G2-M arrest and fibrotic } \\
\text { maladaptive repair. }\end{array}$ & $\begin{array}{l}\text { Fibrosis contributes to chronic kidney disease; knocking out Cyclin G1 } \\
\text { prevented fibrosis in mouse models. Study provides mechanistic insight } \\
\text { into renal fibrosis and identifies therapeutic target. }\end{array}$ & $\begin{array}{l}\text { Wang [103] } \\
\text { Canaud [104] }\end{array}$ \\
\hline $\begin{array}{l}\text { Deregulation of miR-27 a may contribute to canine fibro- } \\
\text { blast activation after coculture with a mast cell tumour } \\
\text { cell line. }\end{array}$ & $\begin{array}{l}\text { CCNG1, a target of miR-27a in canine fibroblasts, is involved in their } \\
\text { activation. "Taken together, our findings are consistent with canine fibro- } \\
\text { blasts being reprogrammed into CAFs... in cancer." }\end{array}$ & Rojas [105] \\
\hline $\begin{array}{l}\text { Altering MYC phosphorylation in the epidermis increases } \\
\text { the stem cell population and contributes to the develop- } \\
\text { ment, progression, and metastasis of SSC cancer. }\end{array}$ & $\begin{array}{l}\text { CDK-mediated c-Myc phosphorylation at Ser- } 62 \text { is increased in clinical } \\
\text { SCC samples relative to normal skin; MYC activation promotes stem } \\
\text { cell renewal and progression from basal stem cell compartments with } \\
\text { malignant transformation. }\end{array}$ & Wang [106] \\
\hline $\begin{array}{l}\text { Prolyl Isomerase Pin1 in Human Cancer: Function, } \\
\text { Mechanism, and Significance. }\end{array}$ & $\begin{array}{c}\text { The Pin1 enzyme mediates cis-trans isomerization of cellular proteins- } \\
\text { specifically, Phospho-Ser/Thr-Pro motifs-acting as an activator of } \\
\text { oncogenes and growth enhancers; promoting tumor initiation, develop- } \\
\text { ment, and drug resistance. }\end{array}$ & $\mathrm{Pu}[107]$ \\
\hline $\begin{array}{l}\text { PIN1 Provides Dynamic Control of MYC in Response to } \\
\text { Extrinsic Signals }\end{array}$ & $\begin{array}{l}\text { PIN1 plays a critical role regulating MYC stability and activity, PIN1 can } \\
\text { interrupt the progression of pS62-MYC through its degradation cascade } \\
\text { by stabilizing Pro63 in the cis-conformation." }\end{array}$ & Cohn [108] \\
\hline
\end{tabular}

In Retrospect, the Year 2019 represents a modern-day annus mirabilis (a year of wonders): a year in which the U.S. Cancer Patient's Right-To-Try legislation (now U.S. Law) empowered the restoration and return of clinical DeltaRex-G (an FDA-qualified IND) the first time in a decade; a year in which Gordon and Hall strived together to shine a collaborative light fantastic one more time upon a concerted, astonishingly-assembled, grass-roots (charitably-funded), biotechnology-enabled, University-supported, FDA-granted, Right-to-Try empowered Rescue Mission of 2019 a medical mission to resurrect the FDA-approved chemistries and manufacturing controls (CMC) needed to rescue the life-saving biotechnologies from desuetude. The genetic reconstruction, bioproduction, and recertification of the requisite plasmid DNAs, with updated CMC and approved vector cGMP [109] returned 
DeltaRex-G to the cancer clinic with FDA approval of the "Blessed Protocol" in 2019 (NCT04091295).

\section{The BLESSED Protocol}

Expanded Access for DeltaRex-G for Advanced Pancreatic Cancer and Sarcoma(s)

\section{... ClinicalTrials.gov Identifier: NCT04091295 [110]}

It bears mentioning, that the demands for scientific integrity, like the demands for empirical truth, are severe; neither have any sympathy for unearned laurels, fame, nor bio-pharmaceutical fortunes which become like chaff the wind drives away. Therefore, due caution, scientific integrity, a protective (do no harm) posture, and a covenant of compliance is well-advised, as we hand-off this Seaworthy Primer on Pathotropic Medicine, from the FDA Centennial Celebrations of 2007 [111] to Veterinary Medicine, with the same idealistic "clinical principles, adages, and aphorisms" that guided research progress, in our time.

Caution! A modern medicine should not be a replicating species! [86]. At this point, a categorical distinction indeed, a moral distinction must be made between the "replication incompetent" retroviral vectors presented herein, which are constructed from inert components with no replication competent characteristics, and the infectious species of viruses that has been advocated in recent years with a disturbing epidemiological naiveté and a less than convincing scientific rationale... Hence, it bears reiterating that DeltaRex-G is the first and only systemically injectable, immunologically stealth, mechanistically defined, genetically stable, certifiably replication-incompetent gene delivery vehicle that is designed and proven to be safe and effective in the clinic [86].

Remembering “Alisomar-1975” International Congress on Recombinant DNA Molecules. Then and there, yonder upon the far-reaching Alisomar State Beaches of the Monterey Peninsula, 140 top bio/life-scientists and physicians, accompanied by lawyers, journalists, and government officials, gathered at the Alisomar Conference Center in Pacific Grove to voice their concerns and to recommend a voluntary moratorium on certain recombinant DNA experiments [112] specifically, experiments that introduced genes which could potentially transform normally innocuous microbes into cancer-causing agents or human pathogens resistant to antibiotics [113] more specifically, the biosafety concerns focused intently on the Simian Virus (SV40), which turns out to be "unexpectedly" dangerous in terms of human health [114]; yet SV40 virology was immensely useful in terms of understanding and eventually utilizing viral gene-expression mechanisms and elements safely for therapeutic gene delivery.

Ultimately, it was agreed that the research should continue but under stringent guidelines, thus marking a historic milestone for science and for public discussion of science policy, leading directly to the formation of the U.S. FDA RAC. Looking back, meeting organizer Paul Berg reflects: "There is a lesson in Asilomar for all of science: the best way to respond to concerns created by emerging knowledge or early-stage technologies is for scientists from publicly-funded institutions to find common cause with the wider public about the best way to regulate as early as possible. Once scientists from corporations begin to dominate the research enterprise, it will simply be too late" [113].

\section{Pathotropic Vector Production: "Points to Consider" for a Comparative Oncology}

DeltaRex-G is a tumor-targeted MLV-based retroviral expression vector ( $\sim 100 \mathrm{~nm}$ ) displaying an amphotropic (panCol) SIG-targeted envelope on its surface to seek-out anaplastic proteins exposed pathologically within the tumor microenvironment [40]; the DeltaRex-G retrovector encodes a cytocidal Cyclin G1 inhibitor, dnG1 (Figure 3A), under the control of a hybrid CMV/LTR promoter [41]. The vector contains the neomycin resistance gene (neo) driven by the SV40 early promoter; neo expression is useful for certifying functional vector titers (gene transfer units/ml) and also for tracking / marking of transgene expression in vivo. However, in the case of a tumor-targeted vaccine (DeltaVax), the neo marker gene was replaced with HSV-tk thymidine kinase gene, a so-called suicide transgene for additional safety: (i) to avoid potential engraftment, (ii) to enable pharmacological control of gene expression with herpetic prodrugs, and (iii) to restrict GM-CSF expression locally within tumors [41].

The targeted DeltaRex-G vector specifically designed for use in humans is produced by transient co-transfection of 3 separate plasmids in HEK 293T (human 293 kidney cells transformed with SV40 large $\mathrm{T}$ antigen) producer cells obtained from a fully validated master cell bank [46,86-88]. The restriction of transgene expression to proliferative cells is a safety feature of the MLVbased vector, while transient transfection versus "stable" producer cells provides for greater genetic fidelity of the IND [116-119]. Moreover, the Delta-Rex (dnG1) and Delta-Vax (GM-CSF) vectors were optimized to eliminate overlapping DNA sequences within the three deconstructed plasmids [41] that might inadvertently recombine to generate unwanted replication-competent retrovirus (RCR): thereby providing for safer (certifiably RCR-free), sterile, clinical- grade expression vectors with consistently high titers (Figure 3B). These efforts of refinement were authorized by the U.S.FDA, which subsequently granted DeltaRex-G "Orphan Drug" and "Fast Track" status.

Biologically, the dnG1 Silver-bullet (packaged in a plasmid) literally "shoots-the- heart-out" of Animal Cell Competence that is, the Cyclin-G1/Cdk/cMyc/Mdm2/ (+/-) p53 Axis, which is conserved at the protein level from the eggs and embryology of sea urchins, frogs, fruit flies, and salamanders, to the regenerative 
stem cells residing within the fragile corpus of mankind. Likewise, the Molecular Biology of enforced Gene Expression, well-known to the kingdom / family vividae, has broad spectrum applications as: the same dnG1 for cats (Figure 4), and dogs, and ponies. Immunologically, however, the Veterinary Producer Cells must naturally be species-specific to exhibit circulatory and surveilling stealth, enabling repeated infusions without untoward immune adverse events. Among the various methods for delivering the three structural "blueprints" [81] of this "Three-Plasmid MLV-based retrovector System" Three plasmid DNAs, in precisely defined ratios to a highly transfectable "Certified producer cell line" which is rationally engineered with powerful synthetic viral elements, and yet is "certifiably-virus free" and demonstrably capable of generating "replication-incompetent" gene expression vectors for cancer gene therapy [116-119].
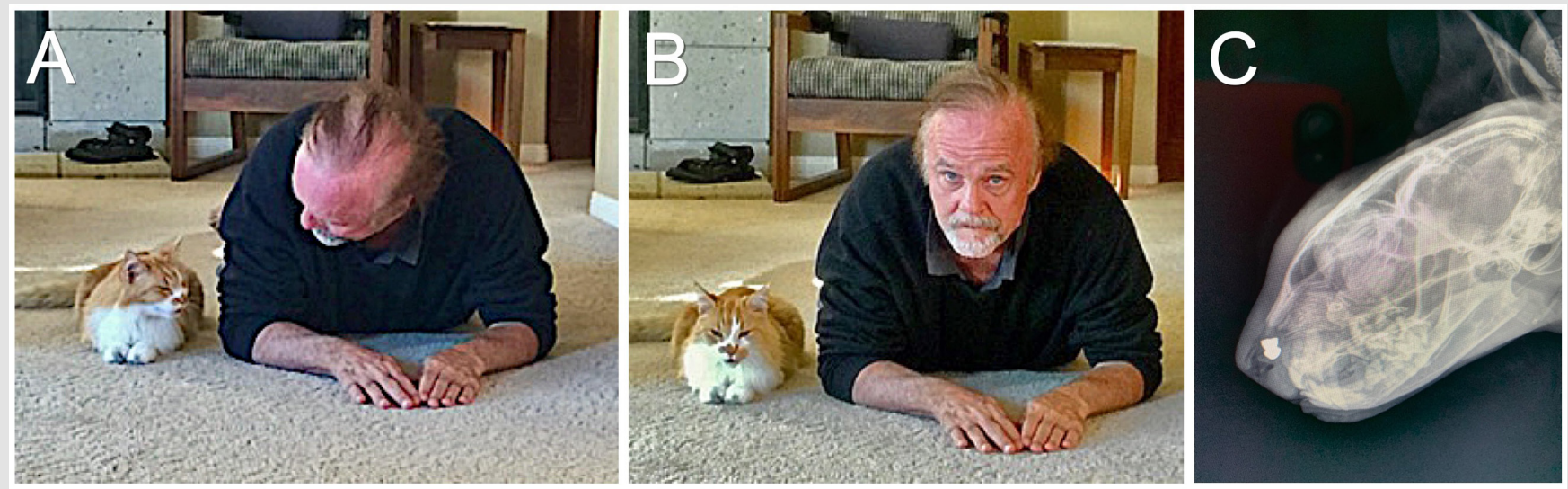

Figure 4: Dr. Frederick L. Hall, at home with his beloved feline companion, Brody Boy, (A, B).

As an adolescent kitten exploring the wild foothills outside greater Los Angeles, little Brody was viciously attacked by an act of human cruelty ... yet the injured kitten managed to drag himself back home, whereby he was saved physically from nearly-fatal stabbings by emergency veterinary abdominal surgery, to enjoy a full trouble-free life well into old age. Ten years after the attack, Brody was adopted by Dr. Hall's family; rather, Dr. Hall was adopted by Brody Boy for psychological reasons obvious above. As Brody approached the advanced age of 20 years-old (90+ in Cornell adjusted cat-years), he experienced a series of natural degenerative issues (osteoarthritis, kidney, thyroid issues, blood pressure, retinopathy) which were readily diagnosed and managed brilliantly with the coordination of primary care, emergency care, and specialized veterinary practices available in Monterey, California. Alas, a recent exploratory X-ray for an emergent sinus issue revealed a tiny metal pellet (C, bullet): a hidden and healed-up remnant of the previous attack on the kitten-despite surgical removal, the bullet (over time) had "initiated" a cancer at the wound-site, which progressed rapidly without remedy to end his brave life. Note: the fabled story of "Androcles and the Lion" was first recorded historically, publicly as a direct observation: Anyone who saw them together exclaimed: "This is the lion that was a man's friend; this is the man who was physician to a lion" [115].

The final product exhibits a vector titer of $2-5 \times 10^{9}$ colony forming units (cfu) per milliliter, a biologic potency of $50-70 \%$ growth inhibitory activity in target cancer cells, less than $550 \mathrm{bp}$ residual DNA, no detectable E1A or SV40 large T antigen, and no detectable replication competent retrovirus (RCR), in compliance with FDA recommendations for retroviral vector-based gene therapy products. The vector formulation is stored in aliquots of 60 $\mathrm{ml}$ in a $250 \mathrm{ml}$ cryobag and kept frozen at $-70^{\circ}$ to $-90^{\circ} \mathrm{C}$ until used. Preparation of the DeltaRex-G vector for patient administration consisted of rapid thawing of the vector in the cryobag in a $37^{\circ} \mathrm{C}$ water bath. The vector is thawed 15 to 30 minutes prior to infusion into the patient and given intravenously at $4 \mathrm{ml} /$ per minute. All personnel who handled and disposed of the vector observed Universal Precautions compliance in accordance with the National Institutes of Health Guidelines for Research Involving Recombinant DNA molecules.

In closing, we concur with ethical and scientific appeals for a more effective, combinatorial, and comparative oncology, as championed by Thomas Efferth, whose scholarship has done much to reveal the efficacy of Artemisinin's (selective ferroptosis) in combination with chemotherapies for both medical and veterinary oncology [120-122], presenting a positive challenge to consider the spontaneous cancers in companion animals as both vital and opportune [123]. It is with confidence in the unity of nature and homeostasis-as reflected in these hard-won molecular, cellular, and genetic understandings that we can expect to learn more about managing cancer metastasis within ourselves, by targeting tumors and managing extended remissions in veterinary medicine.

\section{Acknowledgments, Appreciations, and a Memoriam}

The authors are grateful to the Aveni Foundation A-team Rescue Mission Members: John P Levy (deceased), Rebecca Reed, Heather Gordon, Alison Muldoon, Nicholas J. Hall, Dexter W. Gaston, Jesus Hernández and Brody's Compassionate Veterinary Care in Monterey, California: Carmel Valley Veterinary Hospital, Dr. Aysha Taff and Dr. James Holt. Ophthalmology for Animals, Dr. Elizabeth 
Curto; Pet Specialists of Monterey (emergency surgery), Dr. Greg Marsolas, Dr. Samantha Frankovich, and Dr. Bill Sullenberger; Animal Cancer Center of Monterey, Dr. Teresa Artega, and to Lance Ostendorf for his generous donation and love of Belle, his companion dog. In Memoriam of John P. Levy: scientist, molecular biologist, colleague, and friend an unsung hero of medicine: constructing safe and effective gene-therapy vectors for the next generations.

\section{References}

1. Cech TR (2012) The RNA Worlds in Context. Cold Spring Harbor Perspect Biol 2012: 1-5.

2. Hall F, Morita M, JB Best (1986) Neoplastic Transformation in the Planarian I: cocarcinogenesis and histopathology. J Exp Zoology 240 211-227.

3. Hall F, Morita M, JB Best (1986) Neoplastic Transformation in the Planarian II: ultrastructure of malignant reticuloma. J Exp Zoology 240: 229-244.

4. Morita M (1995) Structure and function of the reticular cell in the planarian Dugesia dorotocephala. In: Cannon L.R.G. (eds) Biology of Turbellaria and some Related Flatworms. Developments in Hydrobiology 108. Springer, Dordrecht.

5. Oviedo NJ, Beane WS (2009) Regeneration: The origin of cancer or a possible cure? Semin Cell Dev Biol. 20: 557-564.

6. Vulliet PR, Hall FL, Mitchell JP, Hardie DG (1989) Identification of a Novel Proline-directed Serine/Threonine Protein Kinase in Rat Pheochromocytoma. J Biol Chem 264: 16292-16298.

7. Hall FL, Mitchell JP, Vulliet PR (1990) Phosphorylation of Synapsin I at a Novel Site by Proline-directed Protein Kinase J Biol Chem 265: 69446948.

8. Hall FL, Vulliet PR (1991) Proline-Directed Protein Phosphorylation and Cell Cycle Regulation. Current Opin. Cell Biol. 3: 176-184.

9. Lu KP, Liou YC, Zhou XZ (2002) Pinning down proline-directed phosphorylation signaling. Trends in Cell Biol 12: 165-172.

10. Lu Z, Hunter T (2014) Prolyl isomerase Pin1 in cancer. Cell Research 24: 1033-1049.

11. Williams R, Sanghera J, Wu F, Carbonaro-Hall D, Campbell DL, et al. (1993) Identification of a human EGF receptor associated (HERA) protein kinase as a new member of the MAPK/ERK family. J Biol Chem 268: 18213-18217.

12. Gordon, EM, Venkatesan, V, Salazar, R. Tang, H, Schmedler-Sapiro K, et al. (1996) Factor XII-induced mitogenesisis mediated via a distinct signal transduction pathway that activates a mitogen-activated protein kinase. Proc Natl Acad Sci USA 93: 2174-2179.

13. Hall FL, Braun RK, Mihara K, Fung YKT, Berndt N, et al. (1991) Characterization of the cytoplasmic proline-directed protein kinase in proliferative cells and tissues as a heterodimer comprised of p34cdc2 and p58cyclin. J Biol Chem 266: 17430-17440.

14. Hall FL, Williams RT, Wu L, Wu F, Carbonaro-Hall DA, et al. (1993) Two potentially oncogenic cyclins, cyclin A and cyclin D1, share common properties of subunit configuration, tyrosine phosphorylation, and physical association with the Rb protein. Oncogene 8: 1377-1384.

15. Peeper DS, Parker LL, Ewen ME, Toebes M, Hall FL, et al. (1993) A- and B-type cyclins differentially modulate substrate specificity Cyclin-Cdk complexes. EMBO J 12: 1947-1954.

16. Elledge SJ, Richman R, Hall FL, Williams RT, Lodgson N, et al. (1002) CDK2 encodes a $33 \mathrm{KDa}$ cyclin A-associated protein kinase and is expressed before CDC2 in the cell cycle. Proc Natl Acad Sci USA 89: 2907-2911.
17. Tuan TL, Cheung DT, Wu L, Yee A, Gabriel S, et al. (1996) Engineering, expression and renaturation of targeted TGF-beta fusion proteins. Connective Tissue Res 34: 1-9.

18. Hall FL, Liu L, Chen ZH, Hu J, Nimni ME, et al. (2000) Design, Expression, and Renaturation of a Lesion-targeted Recombinant Epidermal Growth Factor (EGF)-von Willebrand Factor Fusion Protein: Efficacy in an Animal Model of Experimental Colitis. Intl J Mol Med 6: 635-643.

19. Hall FL, Han B, Kundu RK, Yee A, Nimni ME, et al. (2001) Phenotypic differentiation of TGF-B1-responsive pluripotent pre-mesenchymal prehematopoietic progenitor (P4 Stem) cells from murine bone marrow. J Hematother Stem Cell Res 10: 261-271.

20. Gordon EM, Skotzko MJ, Kundu RK, Han B, Nimni M, et al. (1997) Capture and expansion of bone marrow-derived mesenchymal progenitor cells with a transforming growth factor B1-von Willebrand's factor fusion protein for retrovirus-mediated delivery of coagulation factor IX. Human Gene Therapy 8: 1385-1394.

21. Wu L, Liu L, Yee A, Carbonaro-Hall D, Tolo VT, et al. (1994) Molecular cloning of the human CYCG1 gene encoding a G-type cyclin: Overexpression in human osteosarcoma cells. Oncology Reports 1: 705711.

22. Skotzko M, Wu L, Anderson WF, Gordon EM, Hall FL (1995) Retroviral Vector-mediated gene transfer of antisense cyclin G1 (CYCG1) inhibits proliferation of human osteogenic sarcoma cells. Cancer Research 55: 5493-5498.

23. Zhu NL, Wu LT, Gordon EM, Anderson WF, Starnes VA, et al. (1997) Down-regulation of cyclin G1 expression by retrovirus-mediated transfer of an antisense cyclin G1 gene inhibits vascular smooth muscle cell proliferation. Circulation 96 :628-635.

24. Hung G, Skotzko MJ, Chang M, Zhu NL, Parekh D, et al. (1997) Intratumoral injection of an antisense cyclin G1 retroviral vector inhibits growth of undifferentiated carcinoma xenografts in nude mice. Int'l J Pediatr Hematol Oncol 4: 317-325.

25. Chen DS, Zhu NL, Hung G, Skotzko MJ, Hall FL, et al. (1997) Retroviral vector-mediated transfer of an antisense cyclin G1 construct inhibits osteosarcoma tumor growth in nude mice. Hum Gene Therapy 8: 16671674.

26. Wu L, Yee A, Lui L, Carbonaro-Hall D, Venkatesan N, et al. (1994) Molecular cloning of the human CAK1 gene encoding a Cyclin-dependent Kinase-Activating Kinase. Oncogene 9: 2089-2096.

27. Yee A, Nichols, Nicholas MA, Wu L, Hall FL, et al. (1995) Molecular cloning of CDK7-associated human MAT1, a cyclin-dependent kinase-activating kinase (CAK) assembly factor. Cancer Research 55: 6058-6062.

28. Xu F, Wang Y, Hall FL (2000) Molecular cloning and characterization of FX3, a novel zinc-finger protein. Oncol Reports 7: 995-1001.

29. Kampmeier J, Behrens A, Wang Y, Yee A, Anderson WF, et al. (2000) Inhibition of rabbit keratocyte and human fetal lens epithelial cell proliferation by retroviral-mediated transfer of antisense cyclin G1 and antisense MAT1 constructs. Human Gene Therapy 11: 1-8.

30. Hall FL, Gordon EM, Wu L, Zhu NL, Skotzko MJ, et al. (1997) Targeting retroviral vectors to vascular lesions by genetic engineering of the MoMuLV gp70 envelope protein. Human Gene Therapy 8: 2183-2192.

31. Hall FL, Liu L, Zhu NL, Stapfer M, Anderson WF, et al. (2000) Molecular engineering of matrix-targeted retroviral vectors incorporating a surveillance function inherent in von Willebrand factor. Human Gene Therapy 11: 983- 993.

32. Gordon EM, Zhu NL, Prescott M Forney, Chen ZH, Yu H, et al. (2001) Lesion-targeted injectable vectors for vascular restenosis. Human Gene Therapy 12: 1277-1287.

33. Xu F, Prescott MF, Liu PX, Chen ZH, Liau G, et al. (2001) Long term inhibition of neointima formation in balloon-injured rat arteries by 
intraluminal instillation of a matrix-targeted retroviral vector bearing an improved Cytocidal Cyclin G1 Construct. Intl J Mol Med 8: 19-30.

34. Gordon EM, Liu PX, Chen ZH, Liu L, Whitley MD, et al. (2000) Inhibition of metastatic tumor growth in nude mice by portal vein infusions of matrix-targeted retroviral vectors bearing a cytocidal cyclin G1 construct. Cancer Res 60: 3343-3347.

35. Gordon EM, Liu PX, Chen ZH, Liu L, Whitley M, et al. (2001) Systemic administration of a matrix-targeted retroviral vector is efficacious for cancer gene therapy in mice. Human Gene Therapy 12: 193-204.

36. Lenz HJ, Anderson WF, Hall FL, Gordon EM (2002) Tumor Site Specific Phase I/II Evaluation of Safety and Efficacy of Hepatic Arterial Infusion of a Matrix-Targeted Retroviral Vector Bearing a Dominant Negative Cyclin G1 (dnG1) Construct as Treatment for Colorectal Carcinoma Metastatic to Liver. Human Gene Therapy 13: 1515- 1537.

37. Gordon EM, Lopez FF, Cornelio GH, Lorenzo CC, Levy JP, et al. (2006) Pathotropic nanoparticles for cancer gene therapy. Rexin-GTM IV: Three-year clinical experience. Int'l J Oncol 29: 1053-1064.

38. Chawla SP, Chua VS, Fernandez L, Saralou A, Quon D, et al. (2009) Phase I/ II and and Phase II studies of targeted gene delivery in vivo: intravenous Rexin-G for chemotherapy-resistant osteosarcoma and other sarcomas. Molecular Therapy 17: 1651-1657.

39. Chawla SP, Chua VS, Fernandez L, Saralou A, Quon D, et al. (2010) Advanced Phase I/II studies of targeted gene delivery in vivo: Intravenous Rexin-G for gemcitabine-resistant metastatic pancreatic cancer. Molecular Therapy 18: 435-441.

40. Hall FL, Levy JP, Reed RA, Petchpud WN, Chua VS, et al. (2010) Pathotropic targeting advances clinical oncology: Tumor-targeted localization of therapeutic gene delivery. Oncology Reports 24: 829-833.

41. Gordon EM, Levy JP, Reed RA, Petchpud WN, Liu, Wendler CB, et al (2008) Targeting metastatic cancer from the inside: a new generation of gene delivery vectors enables personalized vaccination in situ. Int'l J Oncol 33: 665-675.

42. Cornelio GH, Lorenzo CC, Lopez FF, Hall FL, Gordon EM (2008) Phase I study of sequential targeted gene delivery: Intravenous infusions of Rexin-G followed by Reximmune-C induce tumor necrosis and recruitment of tumor infiltrating lymphocytes in cancerous lesions. J Clin Oncol 26(15 suppl): 3077

43. Ignacio JG, Chawla SP, Manalo RE, Baniqued L, San Juan FS, et al. (2010) A phase I/II study of intravenous Rexin-G and Reximmune-C for cancer immunotherapy: The Gene Vieve protocol. J Clin Oncology, 2010 ASCO Annual Meeting Proceedings (Post-Meeting Edition) 28 (15 Suppl): 2546.

44. Hall FL, Chawla SP, Chawla NS, Gordon EM (2016) Targeting monoclonal antibodies to the tumor microenvironment for cancer therapy / immunotherapy. J Immunology and Serum Biology 2: 1-7.

45. Hall FL, Gordon EM (2019) Targeting of pharmaceutical agents to pathologic areas using bifunctional fusion polypeptides.

46. Gordon EM, Hall FL. (2010) Rexin-G: A Targeted Genetic Medicine for Cancer. Expert Opinion Biol Ther 10: 819-832.

47. Kim S, Federman N, Gordon EM, Hall FL, Chawla SP (2017) Rexin-G, an XC- /Tumor-Targeted Retrovector for Malignant Peripheral Nerve Sheath Tumor: A Case Report. Mol Clin Oncol 6: 861-865.

48. Stendahl P, Dy G, Chawla SP, Hall FL, Gordon EM (2018) Immune cell trafficking in the tumor microenvironment of human cyclin G1 (CCNG1) inhibitor-treated tumors (Review). British Journal of Cancer Research 1: 202-207.

49. Ignacio JG, San Juan F, Manalo RA, Nategh ES, Tamhane J, et al. (2018) The Genevieve Protocol: Phase I/II evaluation of a dual targeted approach to cancer gene therapy / immunotherapy. Clinics in Oncology 3(1537): 1-7.
50. Gordon EM, Ravicz J, Liu S, Chawla SP, Hall FL. (2018) Applied Cell Cycle Checkpoint Control: The Cyclin G1 / Mdm2 / p53 Axis emerges as a strategic target for 'broad spectrum' cancer gene therapy. Molecular Clinical Oncol 9: 115-134.

51. Al-Shihabi A, Chawla SP, Hall FL, Gordon EM (2018) Exploiting oncogenic drivers along the CCNG1 pathway. Molecular Therapy / Oncolytics 11: 122-126.

52. Yasutis KM, Kozminski KG (2013) Cell cycle checkpoint regulators reach a zillion. Cell Cycle 12: 1501-1509.

53. Horne MC, Goolsby GL, Donaldson KL, Tran D, Neubauer M, et al. (1996), Cyclin G1 and Cyclin G2 comprise a new family of cyclins with contrasting tissue-specific and cell cycle-regulated expression. J Biol Chem 271: 6050-6061.

54. Chen X (2002) Cyclin G: A regulator of the p53-Mdm2 network. Developmental Cell 2: 518-519.

55. Sinha AU, Kaimal V, Chen J, Anil G Jegga AG (2008) Dissecting micro regulation of a master regulatory network. BMC Genomics 9: 19.

56. Ohtsuka T, Ryu H, Minamishima YA, Ryo A, Sam W Lee (2003) Modulation of p53 and p73 levels by cyclin G: implication of a negative feedback regulation. Oncogene 22: 1678-1687.

57. Hagar KM, Gu W (2014) Understanding the non-canonical pathways involved in p53-mediated tumor suppression. Carcinogenesis 35: 740746.

58. Hydbring P, Malumbres M, Sicinski P (2016) Non-canonical functions of cell cycle cyclins and cyclin- dependent kinases. Nat Rev Mol Cell Biol 17: 280-292.

59. Quandt E, Ribeiro MPC, Clotet J (2020) Atypical cyclins: the extended family portrait. Cellular and Molecular Life Sciences 77: 231-242.

60. Bayer FE, Zimmermann M, Fischer P, Christian Gromoll C, Preiss A, et al. (2017) p53 cyclin G cooperate in mediating genome stability in somatic cells of Drosophila. Nature Scientific Reports 7: 17890,

61. Cuadrado A, Lafarga V, Cheung PCF, Dolado I, Llanos S, et al. (2007) A new p38 MAP kinase-regulated transcriptional coactivator that stimulates p53-dependent apoptosis. The EMBO Journal 26: 2115-2126.

62. Lafarga V, Cuadrado A, Angel R. Nebreda AR (2007) p18(Hamlet) mediates different p53-dependent responses to DNA damage-inducing agents. Cell Cycle 6: 2319-2322.

63. Segalés J, Perdiguero E, Muñoz-Cánoves P (2016) Regulation of muscle stem cell functions: a focus on the p38 MAPK signaling pathway. Frontiers in Cell and Developmental Biology 4.

64. Cuadrado A, Corrado N, Perdiguero E, Lafarga V, Mun oz-Canoves P, et al. (2010) Essential role of p18Hamlet/SRCAP-mediated histone H2A.Z chromatin incorporation in muscle differentiation. The EMBO J 29: 2014-2025.

65. Gramantieri L, Ferracin M, Fornari F, Veronese A, Sabbioni S, et al. (2007) Cyclin G1 is a target of miR-122a, a microRNA frequently down-regulated in human hepatocellular carcinoma. Cancer Res 67: 6092-6099.

66. Dai C, Zhang Y, Xu Z, Jin M (2020) MicroRNA-122-5p inhibits cell proliferation, migration and invasion by targeting CCNG1 in pancreatic ductal adenocarcinoma. Cancer Cell Int 20: 98

67. Yan J, Jiang JY, Meng XN, Xiu YL, Zong ZH (2016) MiR-23b targets cyclin G1 and suppresses ovarian cancer tumorigenesis and progression. Journal of Experimental \& Clinical Cancer Research 35: 31

68. Han H, Zhang Z, YANG X, Yang W, Xue C, et al. (2018) miR-23b suppresses lung carcinoma cell proliferation through CCNG1. Oncology Letters 16: 4317-4324.

69. Shang Y, Feng B, Zhou L, Ren G, Zhang Z, et al. (2015) The miR27bCCNG1-P53-miR-508-5p axis regulates multidrug resistance of gastric cancer. Oncotarget 7: 538-549. 
70. Li C, Hu G, Wei B, Wang L, Liy N (2019) IncRNA LINC01494 promotes proliferation, migration and invasion in glioma through miR-122-5p/ CCNG1 axis. OncoTargets and Therapy 12: 7655-7662.

71. García-Gutiérrez L, Delgado MD, Javier León J (2019) MYC Oncogene Contributions to Release of Cell Cycle Brakes. Genes 10: 244.

72. Chen H, Liu H, Qing G (2018) Targeting oncogenic Myc as a strategy for cancer treatment. Springer Nature: Signal Transduction and Targeted Therapy 3: 5 .

73. Seo HR, Kim J, Bae S, Soh JW, Lee YS (2008) Cdk5-mediated phosphorylation of c-Myc on Ser-62 is essential in transcriptional activation of cyclin B1 by Cyclin G1.J Biol Chem 283(23): 15601-15610.

74. Hydbring P, Castell A, Larsson LG (2017) Myc Modulation around the CDK2/p27/SKIP2 Axis. Genes 8: 174.

75. Zhang X, Wang J, Jia Y, Liu T, Wang M, et al. (2019) CDK5 neutralizes the tumor suppressing effect of BIN1 via mediating phosphorylation of c-MYC at Ser-62 site in NSCLC. Cancer Cell Int 19: 226.

76. Balasubramanian A, Subramaniam R, Narayanan V, Annamalai $T$, Ramanathan A (2015) BRD7 promoter hypermethylation as an indicator of well differentiated oral squamous cell carcinomas. Asian Pacific J of Cancer Prevention 16: 1615-1619.

77. Park SW, Lee JM (2020) Emerging Roles of BRD7 in Pathophysiology. Int J Mol Sci 21: 7127.

78. Yu X, Li Z (2015) Long non-coding RNA HOTAIR: A novel oncogene (Review) (2015) Molecular Medicine Reports 12: 5611-5618.

79. Cheng D, Deng J, Zhang B, He X, Meng Z, et al. (2018) LncRNA HOTAIR epigenetically suppresses miR-122 expression in hepatocellular carcinoma via DNA methylation. EBioMedicine 36: 159-170.

80. Bandopadhyay M, Sarkar N, Datta S, Das D, Pal A, et al. (2016) Hepatitis $B$ virus $X$ protein mediated suppression of miRNA-122 expression enhances hepatoblastoma cell proliferation through cyclin G1-p53 axis. Infectious Agents and Cancer 11: 40 .

81. Gordon EM, Hall FL (2005) Nanotechnology blooms, at last (Review) Oncology Reports 13: 1003-1007,

82. Evans CH (2019) The vicissitudes of gene therapy. Bone and Joint Research 8: 469-471.

83. Goswami R, Subramanian G, Silayeva L, Newkirk I, Doctor D, et al. (2019) Gene therapy leaves a vicious cycle. Frontiers in Oncology 9: 1-25

84. Feng M, Jiang W, Kim B, Zhang C, Fu YZ, et al. (2019) Phagocytosis checkpoints as new targets for cancer immunotherapy. Nat Rev Cancer 19: 568-586.

85. Gordon EM, Chan MT, Geraldino N, Lopez FF, Cornelio GH, et al. (2007) Le morte du tumour: Histological features of tumor destruction in chemo-resistant cancers following intravenous infusions of pathotropic nanoparticles bearing therapeutic genes. Int'l J Oncol 30: 1297-1307.

86. Gordon EM, Hall FL (2009) The 'timely' development of Rexin-G: First targeted injectable gene vector (Review) Int'l J Oncol 35: 229-238.

87. Gordon EM, Hall FL (2010) Noteworthy clinical case studies in cancer gene therapy: Tumor- targeted Rexin-G advances as an efficacious anticancer agent. Int'l J Oncol 36: 1341-1353.

88. Gordon EM, Hall FL (2011) Critical Stages in the Development of the First Targeted, Injectable Molecular-Genetic Medicine for Cancer. In Gene Therapy Applications, Prof. Chunsheng Kang (Edn.), ISBN: 978953-307-541-9, InTech Chapter 26: 461-492.

89. Martins F, Sofiya L, Sykiotis GP, Lamine F, Maillard M, et al. (2020) Adverse effects of immune-checkpoint inhibitors: epidemiology, management, and surveillance. Nature Reviews, Clinical Oncology 16: 563-580.

90. Langreth R, Moore SD (1999) Researchers get a dose of reality as logistics stymie gene therapy. The Wall Street Journal.
91. Liu SY, Chawla SP, Bruckner H, Morse MA, Federman N, et al. (2019) Reporting long term survival following precision tumor-targeted gene delivery to advanced chemotherapy-resistant malignancies: An Academic Milestone. Molecular Therapy 27: 133-133.

92. Chawla SP, Bruckner H, Morse MA, Assudani N, Hall FL, et al. (2019) A Phase I-II study using Rexin-G tumor targeted retrovector encoding a dominant-negative Cyclin G1 inhibitor for advanced metastatic cancer. Molecular Therapy, Oncolytics 12: 56-67.

93. Gordon EM, Chawla SP, Hall FL (2019) Survival data following phase 1 / 2 studies using precision tumor-targeted gene delivery to advanced chemotherapy-resistant malignancies (2019) Journal of Global Oncology 5 (suppl 101)

94. Xiao AW, Jia Y, Baughn LB, Pearce KE, Pitel BA, et al. (2020) IGH rearrangement in myeloid neoplasms. Haematologica 105

95. Gordon EM, Szeto C, Ravicz JR, Reddy S, Morse M, Chawla S, et al. (2019) Abstract 2556: Enhanced expression of human cyclin G1 (CCNG1) gene in metastatic cancer, a novel biomarker in development for CCNG1 inhibitor therapy.

96. Wyrwicz LS, Gaj P, Hoffmann M, Rychlewski L, Ostrowski J (2007) A common cis-element in promoters of protein synthesis and cell cycle genes. Acta Biochemica Polonica 54: 89-98.

97. Vellingiri B, Iyer M, Subramaniam MD, Jayaramayya K, Siama Z, et al. (2020) Understanding the role of the transcription factor Sp1 in ovarian cancer: from theory to practice. Int J Mol Sci 21.

98. Žiberna L, Šamec D, Mocan A, Nabavi SF, Bishayee A, et al. (2017) Oleanolic acid alters multiple cells signaling pathways: implication in cancer prevention and therapy. Int J Mol Sci 18: 643.

99. Peron G, Marzaro G, Acqua SD (2018) Known triterpenes and their derivatives as scaffolds for the development of new therapeutic agents for cancer. Current Medicinal Chemistry 25: 1259-1269.

100. Zhao X, Liu M, Li D (2015) Oleanolic acid suppresses the proliferation of lung carcinoma cells by miR-122/Cyclin G1/MEF2D axis. Mol Cell Biochem 400: 1-7.

101. Xu Y, Zhang Q, Miao C, Dongol S, Li Y, et al. (2019) CCNG1 (Cyclin G1) regulation by mutant-P53 via induction of Notch3 expression promotes high-grade serous ovarian cancer (HGSOC) tumorigenesis and progression. Cancer Medicine 8: 351-362.

102. Luan Y, Han T, Liu R, Yang X, Li Q (2019) Cyclin G1 mediates the poor prognosis of breast cancer through expanding the cancer stem cells. J Clin Exp Med 12: 5475-5486

103. Wang M (2019) Cyclin G1 drives maladaptive renal repair. Nature Reviews/Nephrology 15: 191

104. Canaud G, Brooks CR, Kishi S, Taguchi K, Nishimura K, et al. (2019) Cyclin G1 and TASCC regulate kidney epithelial cell G2-M arrest and fibrotic maladaptive repair. Sci Transl Med 11(476).

105. Aguilera-Rojas M, Sharbati S, Torsten, Stein T, Einspanier R (2020) Deregulation of miR-27a may contribute to canine fibroblast activation after coculture with a mast cell tumour cell line. FEBS Open Bio 10: 802-816.

106. Wang X, Langer EM, Daniel CJ, Janghorban M, Wu V, et al. (2020) Altering MYC phosphorylation in the epidermis increases the stem cell population and contributes to the development, progression, and metastasis of squamous cell carcinoma. Oncogenesis 9: 79.

107. Pu W, Zheng Y, Peng Y (2020) Prolyl Isomerase Pin1 in Human Cancer: Function, Mechanism, and Significance. Frontiers in Cell and Developmental Biology 8: 168.

108. Cohn GM, Liefwalker DF, Langer EM, Sears RC (2020) PIN1 Provides Dynamic Control of MYC in Response to Extrinsic Signals. Frontiers in Cell and Developmental Biology 8: 224. 
109. Bennett C (2019) The revival of a forgotten gene therapy with off-theshelf potential. Cancer Therapy Advisor.

110. Gordon EM (2019) BLESSED protocol: Expanded Access for DeltaRex-G for Advanced Pancreatic Cancer and Sarcoma. ClinicalTrials.gov Identifier: NCT04091295.

111. Gordon EM, Hall FL (2007) A primer on pathotropic medicine. In: Celebrating One Hundred Years of the Food and Drug Administration. A special centennial edition. Brooklands New Media Ltd., Oswestry, Shropshire, UK, pp: 80-83.

112. Capron, AM, Schapiro R (2001) “REMEMBER ASILOMAR? reexamining science's ethical and social responsibility." Perspectives in Biology and Medicine 44: 162-169.

113. Berg P (2008) Asilomar 1975: DNA modification secured. (Opinion: Meetings that Changed the World) Nature 455: 290-291.

114. Carbone M, Gazdar A, Butel JS (2020) SV40 and human mesothelioma. (requiem review article). Translational Lung Cancer Res 9(Suppl 1): S47-S59.

115. Rolfe JC (1927) The Attic Nights of Aulus Gellius With an English Translation. Harvard University Press, William Heinemann, LTD, London, UK.

116. Sheridan PL, Bodner M, Lynn A, Phuong TK, DePolo NJ, et al. (2000). Generation of retroviral packaging and producer cell lines for largescale vector production and clinical application: improved safety and high titer. Molecular Therapy2: 262-275.

ISSN: 2574-1241

DOI: 10.26717/BJSTR.2021.35.005736

Erlinda M Gordon. Biomed J Sci \& Tech Res

(c) (P) This work is licensed under Creative

Submission Link: https://biomedres.us/submit-manuscript.php
117. Van der loo JC, Wright JF (2015) Progress and challenges in viral vector manufacturing. Human Molecular Genetics 25(R1): R42-R52.

118. Merten OW, Hebben M, Bovolenta C (2016) Production of lentiviral vectors. Molecular Therapy - Methods \& Clinical Development 3: $1-14$.

119. Cornetta K, Matheson L, Long R, Duffy L (2020) The National Gene Vector Biorepository: Eleven years of providing resources to the gene therapy community. Human Gene Therapy 31: 145-150.

120. Rutteman GR, Erich SA, Mol JA, Spee B, Grinwis GC, et al. (2013) Safety and efficacy field study of artesunate for dogs with non-resectable tumours. Anticancer Research 33: 1819-1828.

121. Breuer E, Efferth $T$ (2014) Treatment of iron-loaded veterinary sarcoma by Artemisia annua. Nat. Prod. Bioprospect 4: 113-118.

122. Efferth $T$ (2017) Cancer combination therapies with artemisinin-type drugs. Review. Biochemical Pharmacology 139: 56-70.

123. Saeed M, Breuer E, Hegazy MF, Efferth T (2020) Retrospective study of small pet tumors treated with Artemisia annua and iron. Intl J of Oncology 56: 123-138.

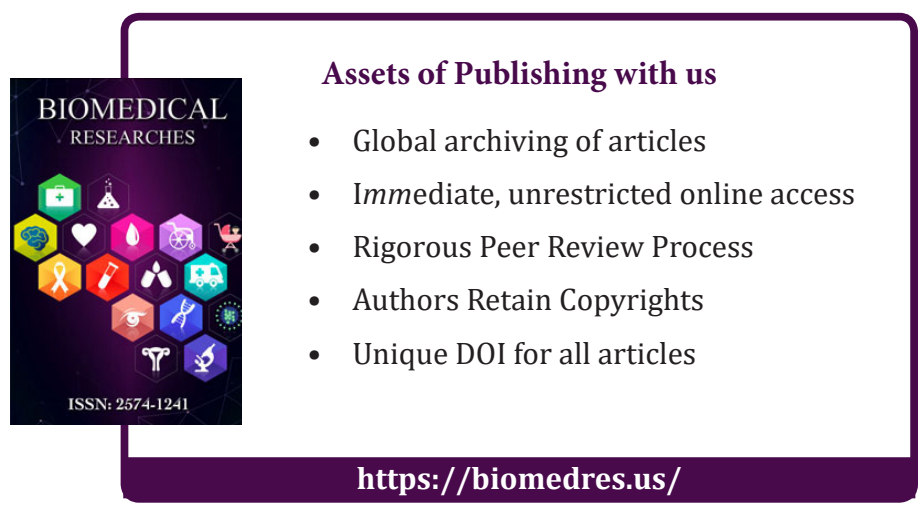

